\title{
EFFECT OF HONEY BEES SUPPLEMENTATION FOR SEMEN EXTENDER ON CRYOPRESERVATION, BACTERIAL ACTIVITY AND FERTILITY TRAITS OF RABBITS
}

\author{
M.E.El-Speiy ${ }^{1}$; El-Sawy ${ }^{1}$, F.B.A., Badri ${ }^{2}$ and T.A. Sadaka ${ }^{1}$ \\ ${ }^{1}$ Anim. Prod. Res. Inst., Agric. Res. Center, Ministry of Agric., Egypt. \\ 2 Poultry Production Department, Faculty Agric., Ain-Shams Univ., Cairo, \\ Egypt. \\ E-mail: Elsawy1966@Gmail.com
}

Twenty V-line male rabbits, ten months age and 80 multiparous does aged 12 months were used for the present study. Three experiments were carried out. First experiment was planned to use honey bee as a component in sperm preservation extender at incubation $\left(37^{\circ} \mathrm{C}\right)$ for up to 6 hours or refrigeration condition (4$6^{\circ} \mathrm{C}$ ) for up to 72 hours. Second experiment was done to study effect of different levels of honey bee on total bacterial count, enterobacteriaceas count, Staph. aureus. Third experiment was designed for studying fertility traits for does artificially inseminated by diluted pooled semen with antibiotics (control) and the best level of honey bees.

Results showed that diluted V-line rabbits semen with 1, 3, or $5 \mathrm{ml}$ honey bee $100 \mathrm{ml}$ extender improved significantly $(P \leq 0.05)$ semen quality increased in percentages of advanced sperm motility and decreased percentages of dead spermatozoa, sperm abnormalities and acrosomal damages during cryopreservation at (4- $6^{\circ} \mathrm{C}$ ) for up to 72 hours or incubation at $37^{\circ} \mathrm{C}$ for up to 6 hours.

Addition of different levels of honey bee to rabbits semen extender resulted in a gradually and significantly decrease $(P \leq 0.05)$ in overall mean of MAD concentration. Total anti-oxidant enzymes activity of rabbit semen extender was increased by increasing honey bee level and this effect was significant $(P \leq 0.05)$, regardless the incubation or storage time. Moreover, the results revealed that the highest honey bee levels had the highest total anti-oxidant capacity value, which was significant $(P \leq 0.05)$ compared to the other levels. Honey bee at different concentrations, generally, had a broad action against total bacterial count of $V$-line rabbit semen, during chilled storage at 4$6^{\circ} \mathrm{C}$ or incubation at $37^{\circ} \mathrm{C}$. 
$V$-line rabbit does artificially inseminated using semen supplemented with a level of honey bee $5 \mathrm{ml} / 100 \mathrm{ml}$ extender showed the best results as compared to the control group. Also, fertility traits were significantly $(P \leq 0.05)$ higher than those inseminated artificially by using semen with antibiotics.

Conclusively, it is concluded that rabbit's semen quality, bacterial activity and fertility traits may be improved with honey bee supplementation to semen extender in V-line rabbits.

Key words: Rabbit semen extender, honey bee, semen quality, fertility traits.

Artificial insemination (AI) a useful assisted reproductive biotechnology has been applied to achieve rapid livestock genetic improvement production (Yimer et al., 2015). Sperm cells are the endpoint of male spermatogenesis and have particular anatomic and metabolic features. Nowadays, Sperm cryopreservation and storage are great demand for conserving the super genetic origins of the males, technologies such as artificial insemination (AI) and in vitro fertilization (IVF) (Medeiros et al., 2002). Efforts to improve the preservation of animal semen are focused on the modification of extenders as well as on the addition of various components to maintain motility, fertilizing capacity and sperm membrane integrity (Marti $e t$ al., 2003 and Riha et al., 2006). Nowadays, semen cryopreservation has many biotechnological applications. It can be used to solve problems of infertility, life threatening diseases, preservation of semen and DNA from endangered species and conservation of biodiversity (El-Sheshtawy et al., 2014). Semen extender is added to maintain spermatozoa metabolic demands, control $\mathrm{pH}$ changes in the extracellular environment of the spermatozoa, minimize cryogenic damage, and also control bacterial contamination.

The presence of variety microorganisms in semen leads reduction of survival rate and fertility of cells and as a consequence, results in non-viable offspring. Therefore, the suppression of undesirable contaminant microbial activity in breeder semen is a mandatory condition for artificial insemination of the pedigree stock (Amangeldy et al., 2013).

Commonly added nutrients in semen extender are simple sugars such as glucose and fructose (Bearden et al., 2004). Egg yolk based extender has been the common and most extensively used extender but it is a good medium for the growth of microorganisms (Geoffrey et al., 1992). Honey bee contains high level of metabolizable energy in form of glucose and fructose and antibacterial that inhibits a broad spectrum of around 60 species of bacteria 


\section{EFFECT OF HONEY BEES SUPPLEMENTATION ON BUCK RABBITS 3}

including aerobes and anaerobes, Gram positives, and negatives activity against microorganisms (Hannan et al., 2004 and AL-Waili, 2004). Also contains minor quantities of amino-acids and vitamins, antioxidant properties, phenolic acids and flavonoid (Andrade et al., 1997) and certain enzymes, ascorbic acid, mineral substances (White, 1975). Molan and Russell (1988) found that honey bee has antibacterial against some microorganisms which are resistant to the common antibiotics used in extenders.

Therefore, the aim of the present study was evaluating the effect of different levels of honey bee addition to tris-based diluent of rabbit's semen during preservation at refrigeration or incubation condition, on fertility traits of rabbit does and semen bacterial counts.

\section{MATERIALS AND METHODS}

Twenty V-line male rabbits, ten months age weighting about $3.5 \mathrm{~kg}$ and 80 multiparous does aged 12 month were used for the present study. They were housed in clean, separate and wire-floor metal cages and maintained under standard laboratory conditions. The ambient temperature was $25 \pm 2^{\circ} \mathrm{C}$ with 55 $64 \%$ relative humidity and a 16:8 hrs light: dark daily. Bucks and does were allowed to a standard pellet diet (17\% crude protein, $2.56 \%$ crude fat and 2500 $\mathrm{Kcal} / \mathrm{kg}$-ration digested energy and $12.5 \%$ crude fiber). Food and water were available $a d$. libitum. All rabbits were kept under the same managerial condition, were healthy and clinically free of external and internal parasites.

Three consecutive semen samples were collected from each male and the interval time between samples was 10 days. Semen was collected artificially by an artificial vagina as described by Lòpez and Alvarino (2000). Semen ejaculates were individually evaluated microscopically and only ejaculates showing advanced sperm motility more than $70 \%$ were pooled and used. Semen was then divided into four equal comparable experimental portions and diluted with tris-honey extender supplemented with $0,1,3$ and $5 \%$ honey bee. The final dilution rate was 1 part semen: 4 parts diluent. The diluted semen was preserved either incubated $\left(37^{\circ} \mathrm{C}\right)$ for up to 6 hours or refrigerated $\left(4-6^{\circ} \mathrm{C}\right)$ for up to 72 hours.

Percentages of advanced motility, dead, abnormality sperms and acrosomal damages were estimated according to Boiti et al., (2005). Samples of diluted semen were taken at 24,48 and 72 hours of preservation at $4-6^{\circ} \mathrm{C}$ and after 0,2 and 6 hours of incubation at $37^{\circ} \mathrm{C}$ for evaluating each of physical semen quality and enzymatic activity. Preserved semen was centrifuged at 3000 r.p.m. for 15 minutes and the supernatant was removed and stored at $-20^{\circ} \mathrm{C}$ until enzymatic assay, malonyaldehyde (MAD) and total antioxidant capacity (TAC) according to Koracevic et al., (2001). All 
Table 1: Composition of Tris- extender with different levels of honey bees.

\begin{tabular}{l|cccc}
\hline \multicolumn{1}{c|}{ Composition } & $\begin{array}{c}\mathbf{0 . 0} \mathbf{~ m l} \\
\mathbf{1 . 0} \text { honey }\end{array}$ & $\begin{array}{c}\mathbf{1 m l} \\
\text { honey }\end{array}$ & $\begin{array}{c}\text { 3ml } \\
\text { honey }\end{array}$ & $\begin{array}{c}\mathbf{5 m l} \\
\text { Honey }\end{array}$ \\
\hline Tris* (gm) & 3.028 & 3.028 & 3.028 & 3.028 \\
Citric acid(gm) & 1.5 & 1.5 & 1.5 & 1.5 \\
Egg yolk (ml) & 5 & 5 & 5 & 5 \\
Sodium penicillin (IU). & 50000 & - & - & - \\
Streptomycin sulphate (mg) & 50 & - & - & - \\
D-glucose (gm) & 1.25 & - & - & - \\
Double distillated water up to & 100 & 100 & 100 & 100 \\
\hline pH & 7.2 & 7.4 & 7.4 & 7.5
\end{tabular}
England.

biochemical parameters were analyzed by commercially available kit methods. GNW-Model: SM-721Spectrophotometers, Absorbance Microplate Reader and other laboratory equipment aids were used for biochemical analysis. Moreover, each parameter was done according to the instructions of its kit.

Semen from the second sample was divided into 4 portions for bacteriological examination. Different levels of honey bee $(0,1,3$, or $5 \mathrm{ml})$ were added to the $1^{\text {st }}, 2^{\text {nd }}, 3^{\text {rd }}$ and $4^{\text {th }}$ fractions, respectively. Total bacterial count; Enterobacteriaceas count, Staph. aureus count was carried out according to Cruickshank et al., (1975) and the extended semen sample was examined bacteriologically by culturing on nutrient agar (Buxton and Fraser, 1977).

The third samples, forty V-line multiparous rabbit does were intramuscularly injected with $20 \mu \mathrm{g}$ gonadotrophin-releasing hormone analogue (GnRH, Recptal, Intervet Co. Lab) to induce ovulation immediately after artificially insemination. Rabbit does were divided into two comparable experimental groups. The $1^{\text {st }}$ and $2^{\text {nd }}$ groups were artificially inseminated by diluted pooled semen with antibiotics (control) and the best level of honey bee showed good semen quality, respectively. The artificial insemination was carried out as described by Boiti et al., (2005). Kindling rate and litter size and weight at birth were recorded.

\section{Statistical analysis:}

Data were analyzed using tow-way analysis of variance for honey bee level and preservation period and their interaction using the General Linear Model (GLM) procedure of SAS (2002) as following model:

$$
\mathrm{Y}_{\mathrm{ijk}}=\mu+\mathrm{T}_{\mathrm{i}}+\mathrm{P}_{\mathrm{j}}+(\mathrm{TP})_{\mathrm{ij}}+\mathrm{e}_{\mathrm{ijk}}
$$

Where: $\mathrm{Y}_{\mathrm{ijk}}=$ An observation; $\mu=$ Overall mean; $\mathrm{T}_{\mathrm{i}}=$ Honey bee level; $\mathrm{P}_{\mathrm{j}}=$ Preservation temperature and period; $\mathrm{TP}_{\mathrm{ij}}=$ Interaction between honey bee level 


\section{EFFECT OF HONEY BEES SUPPLEMENTATION ON BUCK RABBITS 5}

and preservation period; and $\mathrm{e}_{\mathrm{ijk}}=$ Experimental error. When significant differences among means were tested by using Duncan's multiple rang test (Duncan, 1955).

\section{RESULTS AND DISCUSSION}

Data presented in Tables 2 and 3 showed that addition of diluted V-line rabbit semen with 1,3 , or $5 \mathrm{ml}$ honey bee/100 $\mathrm{ml}$ extender improved significantly $(\mathrm{P} \leq 0.05)$ semen quality (represented by increase in percentages of advanced sperm motility and decrease in percentages of dead spermatozoa, sperm abnormalities and acrosomal damages) during cryopreservation at (4$6^{\circ} \mathrm{C}$ ) for up to 72 hours or incubation at $37^{\circ} \mathrm{C}$ for up to 6 hours compared with non-supplemented semen. These results confirm that honey bee in the reactivated medium seemed to have beneficial effect on increasing percentage of motile spermatozoa and consequently increasing semen viability and decreasing the percentages of dead and abnormal spermatozoa and acrosomal damages. Deleterious effects on semen quality were associated with an increase in preservation period. Diluted semen preserved either at $\left(4-6^{\circ} \mathrm{C}\right)$ or at $37^{\circ} \mathrm{C} / 6$ hrs decreased significantly $(\mathrm{P} \leq 0.05)$ the percentages of sperm motility and increased significantly $(\mathrm{P} \leq 0.05)$ the percentages of dead spermatozoa, sperm abnormalities and acrosomal damages (Table 2 and 3). These observations were in agreement with the results obtained by Seleem et al., (2007). The observed reduction in semen quality with progression of conservation period may contribute to the increase in metabolic agent accumulation as a result of sperm anaerobic metabolism leading to changes in both the osmotic pressure and $\mathrm{pH}$ of the media, which might exert a toxic effect on the sperm cell (Riad, 2003). According to Januskauskas et al., (2002) sperm motility induced by cryopreservation is believed to be mainly associated with mitochondrial damage in human spermatozoa; mitochondrial enzymatic activities were shown to be correlated with spermatozoa motility. Furthermore, results from this study revealed that highest semen quality during preservation under refrigeration or incubation conditions was recorded in semen samples supplemented with 3 or 5 $\mathrm{ml}$ honey bee/100 $\mathrm{ml}$ extender. No significant effects were recorded between supplementing 3 and $5 \mathrm{ml}$ honey bee diluted semen on percentage of sperm motility at $5{ }^{\circ} \mathrm{C} / 6 \mathrm{hrs}$. These results supported the improvement of semen quality with honey bee, which may act as antibacterial agent (Kacániová et al., 2012). Kacániová et al., (2012) reported that the component (antioxidant activity, phenolic content, antibacterial agent) play a major factor in sperm protecting sperm against harmful effects of reactive oxygen species and improve sperm motility and membrane integrity, during sperm liquid storage. 
El Speiy et al. 
EFFECT OF HONEY BEES SUPPLEMENTATION ON BUCK RABBITS 7 
Thus, the improvements in semen may be attributed to increase oxidative stability. On the other hand, honey bee is a supersaturated solution of sugars, of which fructose $(38 \%)$, glucose $(31 \%)$ are the main contributors as additive energy source of sperm cells (White, 1975) and amino acids, proteins improved rabbits' semen quality during conservation and in the same time increases fertilizing ability (Elspeiy et al., 2014). Muhammad et al., (2014) reported that honey bee has been used with cryoprotectant medium. However, normally bee honey exists below its melting point, and it is a super cooled liquid. At very low temperatures, honey will not be freeze solid. Instead, as the temperatures become colder, the viscosity of honey increases. Like most viscous liquids, the honey will become thick and condense with decreasing temperature. While appearing or even feeling solid, it will continue to flow at very slow rates. Olayemi et al. (2011) stated that addition of small proportion of honey bee in egg yolk extender ( $5 \mathrm{ml}$ honey $+15 \mathrm{ml}$ egg yolk $+80 \mathrm{ml}$ sodium citrate) gave the highest percent of sperm motility and live/dead ratio of liquid goat cooled semen. Also, Aljady et al. (2000) recorded an antioxidant and antibacterial effects of honey bee and this illustrated the good semen quality of preserved semen with extenders containing honey bee additive. In another study, Akandi et al. (2015) reported that the addition of 1-2\% honey bee to a boar semen extender (based on glucose, sodium bicarbonate, sodium citrate and EDTA) proved its effectiveness in preserving boar semen .Honey bee is also a highly concentrated product and has the potential hyperosmotic extracellular environment around sperm cells that enhances efflux of intracellular fluid thereby minimizing formation of ice crystals inside the sperm cytoplasm which has been linked to sperm damage during cryopreservation (Fakhrildin et al., 2014). This mechanism of protection gives honey bee the property of a nonpermeable cryoprotectant.

More specifically, in vivo supplementation of honey bee to food has been also reported to increase significant concentrations of different antioxidants and a decrease in oxidative stress biomarker present in seminal plasma of humans exposed to a stress factor compared to those who did not take honey bee (Tartibian et al., 2011). Therefore, this could be additional mechanism by which the in vitro addition of honey bee at $2.5 \%$ into tris extender improved quality by reducing percentage of sperm cells with abnormal morphology compared to other tris based extenders tested. The decrease in postcryopreservation semen quality with an increase in honey bee supplement of more than $2.5 \%$ might be associated with excess hyperosmotic extracellular environment created due to high concentration of honey bee that can lead to excessive intracellular dehydration similar to effect of high concentration of non-penetrating cryoprotectants (Lemma, 2011). 


\section{EFFECT OF HONEY BEES SUPPLEMENTATION ON BUCK RABBITS 9}

\section{Oxidative stress markers status:}

Data of Tables 4 and 5 showed the effect addition of different levels of honey bee to rabbit semen extender and the effect of incubation and conservation periods on the lipid peroxidation malonyaldehyde concentration (MAD) and total anti-oxidant capacity (TAC). Results showed that increasing honey bee level supplementation to rabbits semen extender resulted in a gradually and significantly decrease $(\mathrm{P} \leq 0.05)$ in the overall mean of MAD concentration and this effect was honey bee levels-dependent manner, regardless the incubation or conservation time. On the other hand, the MAD concentration in rabbits semen extender was increased significantly $(\mathrm{P} \leq 0.05)$ with increasing the incubation or storage period. Total anti-oxidant enzymes activity of rabbits semen extender was increased by increasing honey bee level and this effect was significant $(\mathrm{P} \leq 0.05)$, regardless the incubation or storage time. Moreover, the results revealed that the highest honey bee levels $(5 \mathrm{ml} / 100$ $\mathrm{ml}$ extender) had the highest total anti-oxidant capacity value, which was significant $(\mathrm{P} \leq 0.05)$ compared to the other levels.

It could explain the role of total anti-oxidants enzymes on sperm functions by understanding the job carried out by these enzymes. From the previous studies, the mammalian sperm membrane is particularly rich in unsaturated fatty acids (PUFA). This renders the sperm very susceptible to lipid peroxidation (LPO), which occurs as a result of the oxidation of the membrane lipids through auto-oxidative reactions that result in the formation of lipid hydro-peroxides (superoxide, hydrogen peroxide and hydroxyl) and malonyaldehyde (MAD) (Bernhard and Phyllis, 1998). Peroxidation can change membrane fluidity and affect several cell functions such as ion permeability and ATPase activity (Tretter and Adam, 1996). Lipid peroxidation of the sperm membrane ultimately leads to the impairment of sperm function due to the attacks by reactive oxygen species acrosome (ROS), which affect and reduce the sperm motility and fertility (Kankofer et al., 2005).

Currently, there is overwhelming evidence that free radicals cause oxidative damage to lipids, proteins, and nucleic acids, leading to many biological complications (Halliwell and Gutteridge 1989). Honey bee can produce many powerful effects as antioxidant (Erejuwa et al., 2010). Completed antioxidant system is required to neutralize and minimize Reactive Oxygen Species (ROS) damage (Hassan et al., 2010).

Several enzymes were detected in honey bee content such as glucose oxidase, diastase, invertase, catalase and peroxidase (Bogdanov et al., 2008). In addition, they studied other active ingredients, organic acids, ascorbic acid, trace elements, vitamins, amino acids, and proteins. 
El Speiy et al. 
EFFECT OF HONEY BEES SUPPLEMENTATION ON BUCK RABBITS 11 
The antioxidant activity of honey bee is generally attributed to its phenolic compounds and flavonoids (Kishore et al., 2011). The main phenolic and flavonoid compounds in honey bee include ellagic, gallic, syringic, benzoic, cinnamic, ferulic acids, myricetin, chlorogenic, coumaric and caffeic acids, hesperetin, isoramnetin, chrysin, quercetin, galangin, luteolin and kaempferol (Petrus et al., 2011) and L-ascorbic acid, $\alpha$-tocopherol and $\beta$ carotene (Balz et al., 1989).

Phenolic compounds are very efficient scavengers of peroxyl radicals because of their molecular structures, which include an aromatic ring with hydroxyl groups containing mobile hydrogens (Aruoma 1994). Moreover, the action of phenolic compounds can be related to their capacity to reduce or chelate divalent ions that catalyze lipid peroxidation (Gazzani et al., 1998).

On the other hand, phenolic antioxidants $(\mathrm{Ar} \mathrm{OH})$ may interrupt radicalinitiated chain reactions by hydrogenatom transfer (Eq. 3) or by electron transfer (Eq. 4) with the formation of phenoxyl radical cation (Ar OH_), which is rapidly and reversibly deprotonated, forming phenoxyl radical(ArO) (Eq. 5) (Ladas et al., 1995). Finally, Honey bee supplementation significantly increased the concentrations of seminal superoxide dismutase (SOD) and catalase (CAT). This antioxidant effect of honey bee was also associated with low elevations in the seminal reactive oxygen species (ROS) and malonyaldehyde (MAD) levels (Tartibian et al., 2011).

\section{Total bacterial count of semen as affected by supplemented honey bee:}

Data in Tables 6 and 7 showed that increasing additive level of honey bee to rabbits' semen extender resulted in a gradually and significantly decrease $(\mathrm{P} \leq 0.05)$ in the overall mean bacterial count and this effect was dependent manner, regardless the incubation or conservation time. Moreover, the results revealed that the highest honey bee levels $(5 \mathrm{ml} / 100 \mathrm{ml}$ extender) had the lowest total bacterial count, which was significant $(\mathrm{P} \leq 0.05)$ compared to the other levels. Also, the total bacterial count in rabbits' semen extender was increased significantly $(\mathrm{P} \leq 0.05)$ with increase the storage period.

Microorganisms can affect the male reproductive function directly, causing the agglutination of motile sperm, reducing the ability of acrosome reaction and causing alterations in cell morphology and indirectly, through the production of reactive oxygen species generated by the inflammatory response to the infection (Moretti et al., 2009). However, there is no complete agreement on the detrimental role of the presence of bacteria in the semen. Detection of bacteria in semen does not necessarily indicate infection, because sample contamination and transference of surface genital colonization can readily occur (Sanocka-Maciejewska et al., 2005). In cases in which bacteria have been 
EFFECT OF HONEY BEES SUPPLEMENTATION ON BUCK RABBITS 13 
detected, sperm morphology was deemed acceptable and few ejaculates contained inflammatory cells. Presence of bacteria in the ejaculates can affect fertilization directly (Morrell and Geraghty, 2006), by adhering to spermatozoa (Diemer et al., 1996), impairing their motility (Kaur et al., 1986), and inducing acrosome reaction (El-Mulla et al., 1996). Endotoxins produced by these bacteria interfere with spermatozoa survival time in semen and cause sperm agglutination and reduced motility (Okazaki et al., 2010). Thus in the use of AI, it is important to control efficiently the population of micro-organisms in the semen.

Sone (1982) showed that the streptomycin and penicillin has low effectiveness against six species of semen microflora. Also, Sevinc et al., (1984) found that a semen with chloramphenicol has the highest fertility (93.1\%), followed by the semen containing penicillin and streptomycin (30$80 \%)$; the semen with ampicillin was the worst one (29\%).

The antimicrobial activity in most honeys is due to the enzymatic production of hydrogen peroxide (Mandal et al., 2010). Its mechanism may be related to the low $\mathrm{pH}$ level of honey and its high sugar content (high osmolarity) that is enough to hinder the growth of microbes and acidic properties of gluconic acid and the antiseptic properties of its $\mathrm{H}_{2} \mathrm{O}_{2}$ (O'Grady et al., 1997).

It is interesting to notice that antimicrobial properties of honey bee in vitro found that $\mathrm{H}_{2} \mathrm{O}_{2}$, methylglyoxal and an antimicrobial peptide, bee defensin-1, are distinct mechanisms involved in the bactericidal activity of honey bee (Khan et al., 2007). Akandi et al., (2015) reported that the dilution of honey bee up to $30 \%$ formed the maximum amount of hydrogen peroxide in media. These inherent properties of honey bee are responsible for its high antimicrobial properties.

In the same trend, Raju and Goli (2013) documented that the antimicrobial properties of honey bee have been attributed to both the hydrogen peroxide as well as non-peroxide components. Non-peroxide factors may also contribute to antimicrobial properties of honey bee such as lysozyme, phenolic acids and flavonoids.

Currently, the best known of the honeys, has been reported to have an inhibitory effect on around 60 species of bacteria, including aerobes and anaerobes, gram-positives and gram-negatives (Mundo et al., 2004).

Honey bee was found to have inhibitory effects on bacterial growth (Staphylococcus aureus, Escherichia coli, Staphylococcus epidermidis and Bacillus cereus) comparable in strength to the antibiotic Penicillin, Streptomycin and Kanamycin (Mierzejewski, 2014). 


\section{Fertility traits:}

It is obvious from the data in Table 8 that V-line rabbit does artificially inseminated using semen supplemented with 5\% of honey bee showed the best results as compared to the control group. The results indicated that kindling rate and litter size and weight at birth were significantly $(\mathrm{P} \leq 0.05)$ higher than those inseminated artificially by using semen with antibiotics (control group).

Table 8. Fertility traits of V-line rabbit does inseminated artificially by semen extender supplemented with honey bee (Ls means \pm SE)

\begin{tabular}{|l|c|c|}
\hline \multirow{2}{*}{\multicolumn{1}{|c|}{ Items }} & \multicolumn{2}{|c|}{ Honey bee levels (ml/100ml extender) } \\
\cline { 2 - 3 } & $\mathbf{0}$ & $\mathbf{5}$ \\
\hline Mated does $(\mathrm{N})$ & 40 & 40 \\
\hline Conceived does $(\mathrm{N})$ & 26 & 34 \\
\hline Kindling rate $(\%)$ & $65.33^{\mathrm{b}} \pm 3.18$ & $84.67^{\mathrm{a}} \pm 2.84$ \\
\hline Litter size at birth & $6.67^{\mathrm{b}} \pm 0.33$ & $9.00^{\mathrm{a}} \pm 0.58$ \\
\hline Litter weight at birth $(\mathrm{g})$ & $266.67^{\mathrm{b}} \pm 1.67$ & $345.33^{\mathrm{a}} \pm 3.76$ \\
\hline Bunny weight at birth $(\mathrm{g})$ & $40.33 \pm 1.86$ & $39.00 \pm 3.08$ \\
\hline
\end{tabular}

Means within the same row $(\mathrm{a}, \mathrm{b})$ bearing different letter superscripts are significantly different $(\mathrm{P} \leq 0.05)$

Energy is very crucial for the maintenance of sperm motility and viability (Machebe et al., 2012). Thus, it is expected that an adequate amount of energy is required by sperm during storage to maintain movement and other physiological functions. Hence, energy substrate like sugars in the storage media forms the source of materials for production of energy for motility.

Average motility of sperm during storage in honey extender was higher than that of other treatments. Honey bees have a multifactorial function. It contains source of energy, antioxidant, antibacterial, amino acid and protein, mineral, other phenolic compounds and flavonoid (Kwakman et al., 2010). These inherent properties of honey are responsible for contributed to the maintenance of high motility of sperm cells over time when stored in honey extenders. Fayemi et al., (2006) found that sperm motility might partly contribute to the conception rate and litter size. On the other hand, improvement of fertility traits as a result of V-line rabbit does artificially inseminated by diluted semen containing honey bee can be attributed mainly to its role in control of bacterial growth in semen. In this respect, Poolperm (2001) showed that the bacterial contamination in semen could cause a tremendous reduction in fertility and breeding performance in several farms.

Conclusively, it could be concluded that rabbits semen quality during preservation at different temperatures and fertility traits of rabbit does inseminated artificially could be improved by adding $5 \mathrm{ml}$ honey bee $/ 100 \mathrm{ml}$ extender diluted semen. 


\section{REFFERENCES}

Abubaker, S.A.; H. Ali; A.M. Fathelrahman and M.A. Ibrahim (2015). Evaluation of antibacterial activity of Sudanese bee honey against four species of bacteria. Amer. Jour. of Res. Commun., 3(4): 132-142.

Akandi, A.; S.O. Ugwu and N.S. Machebe (2015). Survivability of boar sperm stored under room temperature in extenders containing some natural products. Open Access Anim. Physiol., 7: 57-64.

Aljady, A.M.; M.Y. Kamaruddin; A.M. Jamal and M.Y. Mohd Yassin (2000). Biochemical study on the efficacy of Malaysian honey in infected wounds: An animal model. Med. J. Islam. Acad. Sci., 13(3): 125-132.

AL-Waili, N.S. (2004). Investigating the antimicrobial activity of natural honey and its effects on the pathogenic bacterial infection of surgical wounds and conjunctiva. Medicinal Food, 7(2): 210-222.

Amangeldy, R.;. N.Z. Eleuqalieva; K.M. Lakhanova; L.M. Mambetova; I.A. Makhatova and G. Khalikova (2013). Development of Antibacterial complex for Sanitation of Boar and Bull Semen. Life Science Journal, 10 (12s): 592-596.

Andrade, P.; F. Ferreres and M.T. Amaral (1997). Analysis of honey phenolic acids by HPLC, its application to honey botanical characterization. J. Liq. Chromatogr Relat Technol., 20: 2281-8.

Aruoma, O.I. (1994). Nutrition and health aspects of free radicals and antioxidants. Food Chem. Toxicol., 32: 671-683.

Balz, F.; Laura England and B.N. Ames (1989)., Medical Sciences. Proc. Natl. Acad. Sci. USA, vol 86, pp. 6377-6381.

Bearden, H.J. J.W. In Fuquay and S.T. Willard (2004). Applied Animal Reproduction. $6^{\text {th }}$ Edition. Pearson Education, Inc., Upper Saddle River, New Jersey. (eds).

Bernhard, H. and G. Phyllis (1998). Suggestions for pharmacological and nutritional management strategies. J. Spinal. Cord. Med., 21: 309-334.

Bogdanov, S.; T. Jurendic; R. Sieber and P. Gallmann (2008). Honey for nutrition and health: A review. J. Am. Coll. Nutr., 27: 677-689.

Boiti, C., Castellini, M., Thau-Clément, M., Besenfelder, U., Liguori, L., Renieri, T. and Pizzi, F. (2005). Guidelines for the handling of rabbit bucks and semen. World Rabbit Science, 13, 71-91.

Buxton, A. and G. Fraser (1977). Animal Microbiology. Vol. 1., Blackwell Scientific Publications.

Cruickshank, R.; J.T. Duguid; B.P. Marmion and R.H.A. Swain (1975). Medical Microbiology. Churchill Livingston Edinburg and New York, $12^{\text {th }}$ Ed. Vol. II. 
Diemer, T., Weidner, W., Michelmann, H. W., Schiefer, H. G., Rovan, E., Mayer, F. (1996). Frozen bovine semen. 1.Control of Mycoplasmas, Influence of Escherichia coli on motility venerealis and parameters of human spermatozoa in vitro. Int. J. Androl., 19: 271- 277.

Duncan D. B. (1955). Multiple range and multiple $F$ tests. Biometrics, 11:1-42.

El-Mulla, K.F.; F.M. Kohn and M. Dandal (1996). Bacterial contamination In vitro effect of Escherichia coli on human sperm acrosome reaction. Arch. Androl., 37: 73-78.

El-Sheshtawy Reda I., Walid S. El-Nattat, Hussein A. Sabra and Amal H. Ali (2014). Effect of honey solution on semen preservability of local breeds of cattle bulls. World Applied Sciences Journal, 32 (10): 20762078.

El-Speiy, M.E.; A.E. Elkomy and K.I. Kamel (2014). Effect of Adding Protein High Viscosity (Gelatin) in Tris Extender on Semen Conservation Status, Fertility Rates, Antioxidant Status and Sex Ratio of Rabbits. Global Veterinaria, 12(6): 840-849.

Erejuwa, O.O.; S. Gurtu; S.A. Sulaiman; M.S. Wahab; K.N. Sirajudeen and M.S. Salleh (2010). Hypoglycemic and antioxidant effects of honey supplementation in streptozotocin-induced diabetic rats. Int. J. Vitam. Nutr. Res., 80: 74-82.

Fakhrildin, M.B.; M.R. Rana and A.R. Alsaadi (2014). Honey supplementation to semen-freezing medium improves human sperm parameters post-thawing. J. Family and Reprod. Health, 8: 27-31.

Fayemi, O.; H.S. Joo and A.G. Hunter (2006). Effect of sperm immunization of male rabbits on sperm quality, conception rate and litter size. Pak. Vet. Journal, 26: 36-40.

Ferreres, F.; A. Ortiz; C. Silva; C. Viguera; F.A. Barbera'n and F.T. Lorente (1992). Flavonoids of "La Alcarria” honey. Z. Lebensm Unters Forsch, 194: 139-43.

Gazzani, G.; A. Papetti; M. Daglia. F. Berte and C. Gregotti (1998). Protective activity of water soluble components of some common diet vegetables on rat. Liver microcosms and the effect of thermal treatment. J. Agric. Food. Chem., 46: 4123-4127.

Geoffrey, H.A.; E.N. David and P. Harold (1992). Artificial Insemination. In Veterinary Reproduction and Obstetrics, $6^{\text {th }}$ edition, Sunders, pp:567.

Halliwell, B. and J.M.C. Gutteridge (1989). Free Radicals in Biology and Medicine. $2^{\text {nd }}$ ed., Clarendon Press, Oxford, UK, pp. 51-57. 
Hannan, A.; M. Barkaat; S. Saleem; M. Usman and W.A. Gilani (2004). Manuka honey and its antimicrobial potential against multi drug resistant strains of Typhoidal salmonellae, Ph.D. Thesis, Department of Microbiology, University of Health Science, Lahore, Pakistan.

Hassan, M.I.; G.M. Mabrouk; H.H. Shehata and M.M. Aboelhussein (2010). Antineoplastic effects of bee honey and Nigella sativa on hepatocellular carcinoma cells. Integr. Cancer Ther., 10.1177/ 1534735410387422 .

Januskauskas, A. and H. Zillinskas (2002). Bull semen evaluation post-thaw and relation of semen characteristics to bull's fertility. Veterinari Jair Zootechnika, 17: 1392-2130.

Kacániová, M.; N. Vuković; R. Chlebo; P. Haščík; K. Rovná; J. Cubon; M. Dżugan and A. Pasternakiewicz (2012). The antimicrobial activity of honey, bee pollen loads and bees wax from Slovakia. Arch. Biol. Sci., Belgrade, 64: 927-934.

Kankofer, M.; G. Kolm; J. Auri h and C. Auri h (2005). Activity of glutathione peroxidase, superoxide dismutase and catalase and lipid intensity in stallion semen during storage at $5^{\circ} \mathrm{C}$. Theriogenology, 4: 63135.

Kaur, M.; K.K. Tripathi; M.R. Bansal; P.K. Jain and K.G. Gupta (1986). Bacteriology of cervix incases of infertility: effect on human sperm. Am. J. Reprod. Immunol. Microbiol., 12: 21-24.

Khan, F.R.; Z. Ul Abadin and N. Rauf (2007). Honey: Nutritional And Medicinal Value. Int. Journal Clin. Pract., 61: 1705-1707.

Kishore, R.K.; A.S. Halim; M.S. Sya ana and K.N. Sirajudeen (2011). Tualang honey has higher phenolic content and greater radical scavenging activity compared with other honey sources. Nutrition Res., 31: 322-325.

Kora $\triangle$ evi $\triangle D . G$;V.Djordjevi $\square$ and V.S.Andrejevi $\square$ (2001). Method or the measurement of antioxidant activity in human fluids. Journal of Clin. Pathol., 54: 356-361.

Kwakman, P.H.; A.A. Velde; L. de Boer; D. Speijer; C.M. Vandenbroucke-Grauls and S.A. Zaat (2010). How honey kills bacteria. FASEB J. 24(7): 2576-2582.

Ladas, S.P.; D.N. Haritos and S.A. Raptis (1995). Honey may have a laxative effect on normal subjects because of incomplete fructose absorption. Am. Journal of Clin. Nutr., 62: 1212-1215.

Lemma, A. (2011). Effect Of Cryopreservation On Sperm Quality And Fertility. In: M. Manafi (ed), Artificial Insemination in Farm Animals. Published online by In Tech., pp. 191-216. 
Lopez, J. and Alvariño, J.M.R. (2000). Effects of added caffeine on results following artificial insemination with fresh and refrigerated rabbit semen. Anim. Rep. Sci., 58 (1-2): 147-154.

Machebe, N.S.; S.O. Ugwu and N.E. Ezume (2012). Differential dietary energy effects on semen characteristics of indigenous turkeys reared in a humid tropical environment. Indian J. Anim. Res., 46(4): 341-347.

Mandal, S.; M. Deb Mandal and N.K. Pal (2010). Synergistic antiStaphylococcus aureus activity of amoxicillin in combination with Emblicaofficinalis and Nymphaeodorata extracts. Asian Pac. Journal of Trop. Med., 3: 711-714.

Marti, J. I.; E. Marti; J.E. cebrian-perez and T. muino-blanco (2003). Survival rate of antioxidant enzyme activity of ram spermatozoa after dilution with different extenders or selection by a dextran swim-up procedure. Theriogenologyram semen. Acta. Vet. Hung., 50(2): 235-245.

Medeiros, C.M.; F. Forell; A.T. Oliveira and J.L. Rodrigues (2002). Current status of spermcryopreservation: why isn't better. Theriogenol., 57: 327-344.

Mierzejewski, M. (2014). The antimicrobial effects of royal jelly, propolis and honey against bacteria of clinical significance in comparison to three antibiotics. College of Arts \& Sciences/Biology.

Molan, P.C. and K.M. Russell (1988). Non-peroxide antibacterial activity in some New Zeland honeys., J. Apic. Res., 27(10):62-67.

Moretti, E.; S. Capitani; N. Figura; A. Pammolli; M. Grazia Federico V. Giannerini, and G. Collodel (2009). The presence of bacteria species in semen and sperm quality. J. Assist. Reproduction Genet., 26: 47-56.

Morrell, J.M. and R.M. Geraghty (2006). Effective removal of equine arteritis virus from stallion semen. Equine Vet. Journal, 38: 224-9.

Muhammad, M.R.; M.D. Fakhrildin; A. Rana and R. Alsaadi (2014). M.Sc. Honey Supplementation to Semen-Freezing Medium Improves Human Sperm Parameters Post-Thawing. Journal of Family and Reproductive Health, 27-31.

Mullai, V. and T. Menon (2007). Bactericidal activity of different types of honey against clinical and environmental isolates of Pseudomonas aeruginosa. Journal of Alternative and Complementary Medicine, 13 (4): 439-441.

Mundo, M.A.; O.L. Padilla-Zakour and R.W. Worobo (2004). Growth inhibition of food borne pathogens and food spoilage organisms by select raw honeys. Int. Journal Food Microbiol., 97: 1-8.

O'Grady, F.W.; H.P. Lambert; R.G. Finch and D. Greenwood (1997). Antibiotic and Chemotherapy. 7thedn. New York: Churchill Living Stone. 
Okazaki, T.; T. Mihara; Y. Fujita; S. Yoshida; H. Teshima; M. Shimada and B. Polymyxin (2010). Neutralizes bacteria-released endotoxin and improves the quality of boar sperm during liquid storage and cryopreservation. Theriogenology, 74(9): 1691-1700.

Olayemi, F.; R. Adedayo; R. Muhummad and E. Bamishaiye (2011). The nutritional quality of three varieties of zobo (Hibiscus sabadariffa) subjected to the same preparation condition. Plant Food Hum. Nutr., 6: 10-15.

Oyeleke, S.B.; B.E. Dauda; T. Jimoh and S.O. Musa (2010). Nutritional analysis and antibacterial effect of honey on bacterial wound pathogen. Journal of Applied Sciences Research, 6(11): 1561-1565.

Petrus, K.; H. Schwartz and G. Sontag (2011). Analysis of flavonoids in honey by HPLC coupled with colorimetric electrode array detection and electrospray ionization mass spectrometry. Annual Bio. Chem., 400: 2555-2563.

Poolperm, P. (2001). Factors influencing semen quality and fertility in boars. $\mathrm{Ph}$. D. Thesis, College of Veterinary Medicine, North Carolina State University, Raleigh, NC.

Raju, V.N and D. Goli (2013). In-vitro comparative antimicrobial activity of commercial and raw honey against various bacteria isolated from ear discharges. Acad. Journal Pharm., 2(1): 5-11.

Riad, R.M. (2003). A comparative study of different additives of extended rabbit semen. Journal of Egypt. Vet. Med. Assoc., 63: 351-361.

Riha, L.; D. Apolen; J. Pivko; P. Grafenau and E. Kubovicova (2006). Influence of implememtors on sheep fertility out of season. Slovak Journal of Anim. Sci., 4: 180-182.

Rodin, D.M.; D. Larone and M. Goldstein (2003). Relationship between semen culture, leukopermia and semen analysis in men undergoing fertility evaluation. Fertil Steril., 79(3): 1555-8.

Sanocka-Maciejewska, D.; M. Ciupinska and M. Kurpisz (2005). Bacterial infection and semen quality. J. Reprod. Immunol., 67: 51-6.

SAS, (2002). SAS/ STAT User's guide statistics. SAS Institute INC., Cary, NC, USA.

Seleem, T.S.T.; K.H. El-Kholy and T.A. El-Aasar (2007). Effect of Arak (Salvadorapersica) aqueous extract on rabbit semen preservation, microbial contamination and artificial insemination. The $5^{\text {th }}$ Inter. Con. on Rabbit Prod. in Hot Clim., Hurghada, Egypt, 381- 390.

Sevinc, A.; N. Yurdaydin; N. Tekin; A. Ekici and N. Aydin (1984). Different antibiotics obtained by participating frozen bull semen donor Fertility. Ankara Univ., 31(4): 491-497. 
Sone, M. (1982). Effect of various antibiotics on the control of bacteria in boar semen. Veter. Rec., 111(3): 11-14.

Tartibian, B.; M.B. Hajizadeh and A. Abbasi (2011). The effects of honey supplementation on seminal plasma cytokines, oxidative stress biomarkers and anti-oxidants during 8 weeks of intensive cycling training. Journal of Andrology, 33(3): 449-461.

Tretter, L. and V. Adam-Vizi (1996). Early events in free radical-mediated damage of isolated nerve terminals: effects of peroxidase on membrane potential and intracellular $\mathrm{Na}_{-}$and $\mathrm{Ca} 2$ _ concentrations. Journal of Neurochem., 66: 2057-2066.

White, J.W. (1975). Composition of Honey. In: Crane E, Ed. Honey, a comprehensive survey. London: Bee Research Association and Chalfont St Peter, 157-206.

Yimer, N.; N. Muhammad; K. Sarsaifi; Y. Rosnina; H. Wahid; A.M. Khumran and A. Kaka (2015). Effect of honey supplementation into Tris Extender on Cryopreservation of Bull Spermatozoa. Journal of Anim. Sci., 18(2): 47-54.

$$
\begin{aligned}
& \text { تأثير إضافة عسل التحل لمخفف سائل منوى الأرانب على حفظ الحيوانات } \\
& \text { المنوية والنشاط البكتيرى وصفات الخصوية الخفية }
\end{aligned}
$$

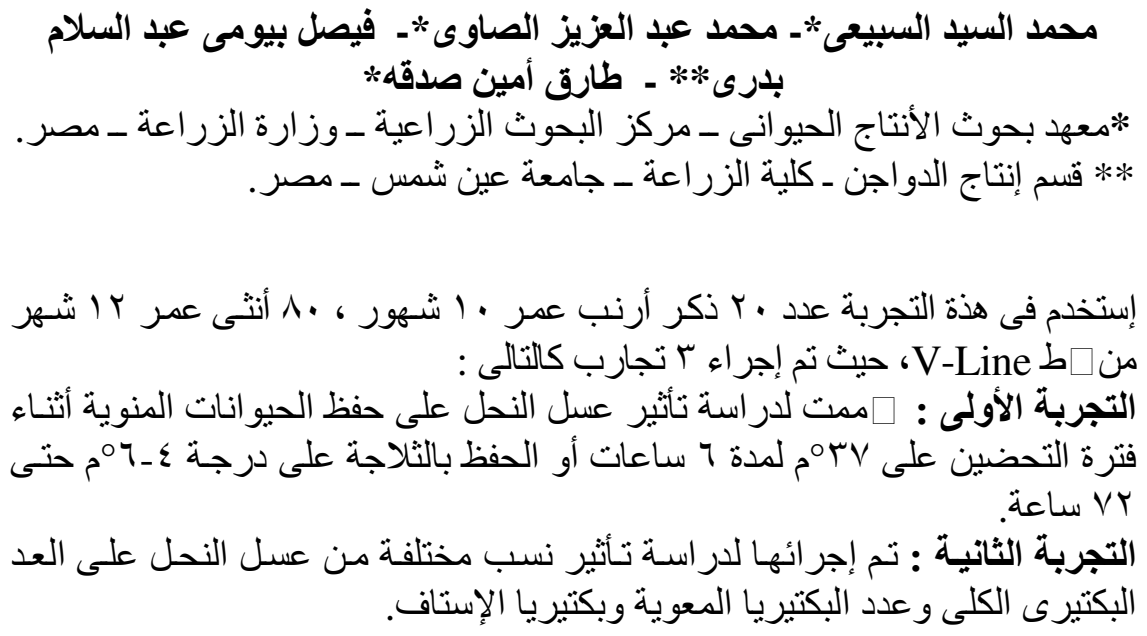




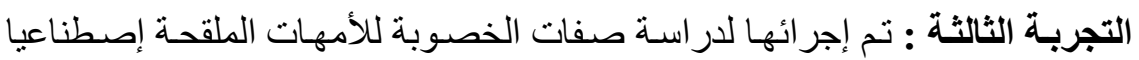

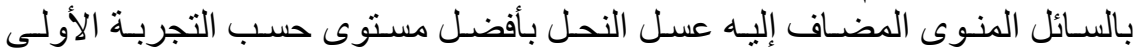
مقارنة بالمضاف إليه مضادات حيوية (كنترول). وقد أوضحت النتائج مايلى:

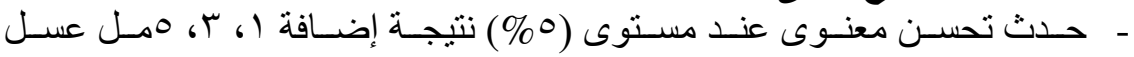

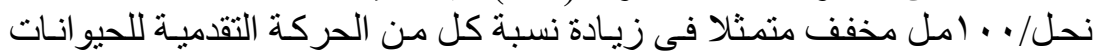

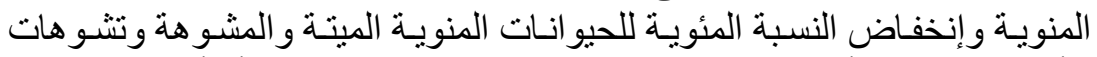

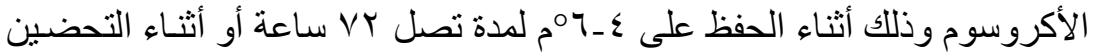

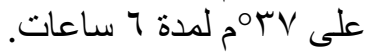

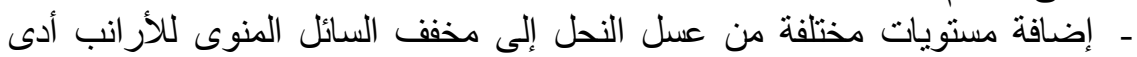

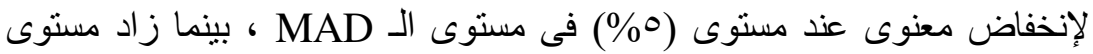

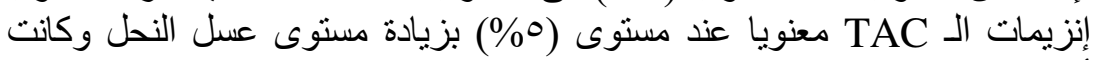

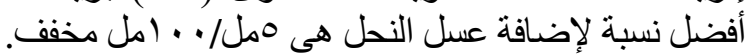

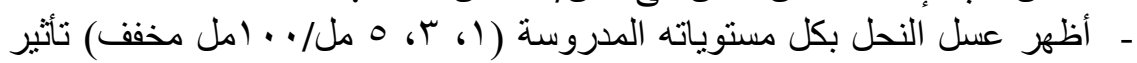

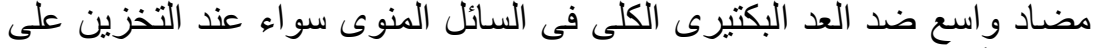

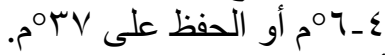

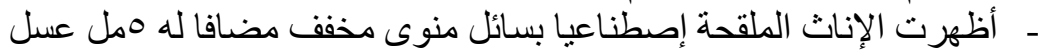

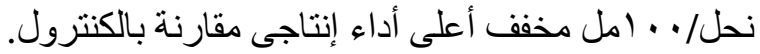

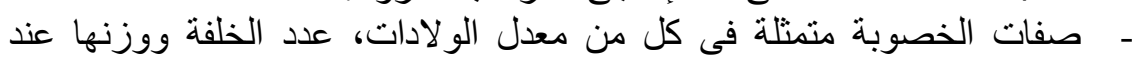

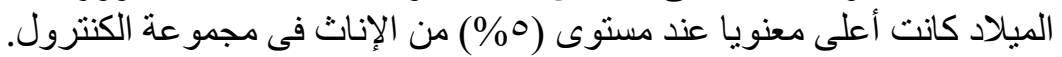

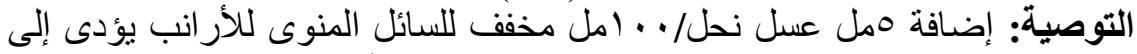

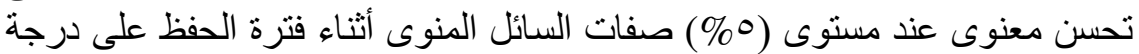

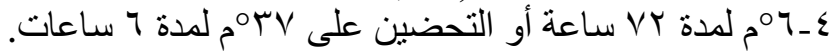

